\title{
Hydrotechnical arrangements influence on morphological and hydrological characteristics of Crişul Negru River and its tributaries - Western Apuseni Mountains, Romania
}

\author{
Dan-Mircea MIHALEA ${ }^{1 *}$, Gheorghe S,ERBAN ${ }^{2}$, Ruth PERJU ${ }^{3}$ and Iulia-Nicoleta LUPU
}

\begin{abstract}
Authors' affiliations and addresses:
${ }^{1}$ University of Oradea, Faculty of Geography, Tourism and Sport, Universităţii Str., no. 1, Oradea, Jud. Bihor, Romania

e-mail: mirceamihalea@yahoo.com

${ }^{2}$ Babeș-Bolyai University, Faculty of Geography, Clinicilor Str., no. 5-7, Cluj-Napoca, Jud. Cluj, Romania

e-mail: gheorghe.serban@ubbcluj.ro

${ }^{3}$ National Institute of Hydrology and Water Management, București-Ploiești Road, no. 97E, București, Romania

e-mail: ruth.perju@hidro.ro
\end{abstract}

${ }^{4}$ University of Bucharest, Faculty of Geography, Doctoral School "Simion Mehedinți", Nicolae Bălcescu Bld., no. 1, București, Romania

e-mail: merluscaiulia@gmail.com

*Correspondence:

Burgundia Mică Str., no. 6, Beiuș, Jud. Bihor, Romania

tel.: +40744114446

e-mail: mirceamihalea@yahoo.com

Funding information:

Funding Agency: Human Capital Operational

Program 2014-2020

Grant Number: 123008

\section{Acknowledgement:}

The paper is funded by the Project "SmartDoct High quality programs for $\mathrm{PhD}$ students and postdoctoral researchers of the University of Oradea for increasing the relevance of research and innovation in the context of the regional economy"

How to cite this article:

Mihalea, D.M., Şerban, G., Perju, R. and Lupu, J.N. (2021). Hydrotechnical arrangements influence on morphological and hydrological characteristics of Crişul Negru River and its tributaries - Western Apuseni Mountains,

Romania. Acta Montanistica Slovaca, Volume 26 (2), 352-363

DOI:

https://doi.org/10.46544/AMS.v26i2.13

\begin{abstract}
The anthropic interventions on riverbeds and banks have a direct and irreversible influence on the flow regime, primarily by changing the hydraulic characteristics of rivers, like channel slope and/or geometry, channel roughness, flow depth, consequently water velocity, propagation time of floods, etc. In the Upper Basin of the Crişul Negru River, the first hydro-technical arrangements were made in the $18^{\text {th }}$ and $19^{\text {th }}$ centuries, mainly for flood mitigation and swampy areas amelioration. But the most important and extensive works were designed following the exceptional floods of 1980-1981 (consolidations of banks, embankments, regularizations, bottom sills, etc.) and at the end of the $20^{\text {th }}$ century. The purpose of the paper is to emphasize the effects of the hydro-technical works on both the morphology of the riverbed and the flow regime (average, minimum and maximum flow) of the most affected rivers in the study area. The data utilized are elevation profiles, stages and discharges recorded on more than 40 years at four gauging stations, namely including periods before and after the execution of the extensive works. The positive and negative influences of the arrangements are highlighted through statistical analysis and trend detection in data series, corroborated with the commissioning of the hydro-technical works and the evolution of rivers' morphology.
\end{abstract}

\section{Keywords}

Hydro-technical arrangements, anthropic influence, hydrological regime, Crișul Negru River 


\section{Introduction}

The need for intervention in the natural characteristics and behaviour of rivers derives from the measures required by the water management policies, whose main role is to protect human communities against extreme water phenomena and, at the same time, to ensure the proper functioning of all water-related economic activities (Şelărescu and Podani, 1993; Sofronie, 2000; Șerban et al., 2004).

One of the purposes of the anthropic interventions on rivers is the management of extreme hydrological events (flood control and water scarcity prevention), namely the mitigation of the consequences of such phenomena on the human communities and economic activities (Teodorescu et al., 1982; Diaconu, 1999; Șerban, 2007).

The hydro-technical arrangements, although they are very often essential for the maintenance and development of the human society functionalities, through their intrusive character, have a major impact on both the hydrological regime of rivers and their natural morphological evolution (Ujvari, 1972; Ichim and Rădoane, 1986; Sofronie, 2000; Șerban, 2007).

Complex studies on the morphodynamic characteristics of watercourses or changes induced by the anthropogenic factor have been undertaken by various authors, especially geomorphologists, from pioneering (Wolman, 1954; Leopold and Wolman, 1957; Leopold and Wolman, 1960) to more recent engineering studies (Chow, 1981; Simon, 1995; Obodovsky, 2004; Cencetti and Tacconi, 2005; Manning, ed., 2011; Sergaliev and Akhmedenov, 2014; Vesipa et al., 2018; Zhou et al., 2018; Bosa et al., 2020).

Some of the works also emphasize the benefits or protections brought by the arrangements of hydro-technical systems in urban areas (Sekulic and Cipranic, 2015), while other works focus on models of the riverbed or the related river basin (Adamec et al., 2012; Mandarin et al., 2020).

Other works focus more on the study and analysis of the vulnerability of the anthropogenic environment to floods, going on numerical models and multicriteria analysis, in the study of basins of cross-border interest or on concentrated runoff in collectors (Neuhold et al., 2011; Blistanova et al., 2016; Zelenakova et al., 2018).

Somewhat more recent concerns related to the anthropogenic impact on riverbeds or on runoff in urban areas have also come to the attention of researchers, conducting studies that can underlie the development of urban space, of decision-making on its development (Zelenakova et al., 2019; Sabău et al., 2020).

Romanian literature did not hesitate to react by publishing studies on riverbed dynamics and the involvement of the anthropogenic factor in this process, recording numerous works, most of them of geomorphological nuance, but also technical or related to the risks induced by anthropogenic intervention: Ichim and Rădoane, 1986; Ichim et al., 1989; Mititelu, 2010; Loghin et al., 2011; Romanescu et al., 2011; Zaharia et al., 2011; Roșian et al., 2012; Costea, 2013; Cîrţînă et al., 2013; Pandi and Horvath, 2013; Cârstinoiu et al., 2017; Danalache et al., 2020 etc.

The assessment of the degree to which the characteristics of rivers are affected by the hydro-technical arrangement is of great importance for future sustainable water resources management policies.

The present paper aims to emphasize the anthropic influence on the liquid flow and on the natural evolution of rivers in the Upper Basin of the Crişul Negru River, where, in time, the interventions on riverbeds became significant (Hydrological Monograph of Crișuri Watershed, 1968). The objective is met through the analysis of hydrological data for the three phases of the hydrological regime: high, mean, and low flows.

\section{Data and methods}

The study is based on hydrological, cartographic data, and information on hydro-technical arrangements.

The hydrological data refers to continuous data series and elevation profiles of cross-sections obtained at the gauging stations (g.st.) at which the hydrological regime and morphology are most affected by the interventions (Tab. 1). The data utilized are part of the National Hydrological Database and were obtained through the "Romanian Waters" National Administration. The observation period varies depending on the availability of the data.

Tab. 1. Gauging stations, periods, and parameters analyzed

\begin{tabular}{|c|c|c|c|}
\hline Gauging station & River & Observation period & Parameters \\
\hline Beiuş & Crișul Negru & $1963-2018$ & \multirow{4}{*}{$\begin{array}{l}\text { Elevation profiles of cross-sections* } \\
\text { Stage: monthly averages } \\
\quad \text { annual maximums and minimums } \\
\text { Discharge: monthly averages } \\
\quad \text { annual maximums and minimums } \\
\text { Hydrographs of significant floods** }\end{array}$} \\
\hline Pietroasa & Crișul Pietros & $1963-2018$ & \\
\hline Beiuș & Nimăiești & $1973-2018$ & \\
\hline Ştei & Crișul Băița & 1963-2018 & \\
\hline
\end{tabular}

The cartographic data refers to raster (the Digital Terrain Model - SRTM90) and vector data (regarding the geographical aspects of the study area, including the location and type of the hydro-technical arrangements), processed in a GIS environment. 
The information regarding the hydro-technical arrangements was provided by the Bihor Water Management System and consists of technical data (type, length, purpose, etc.) on constructions and regularizations conducted and taken on record in the study area, as well as their location on rivers.

To highlight the intensity and the characteristics of anthropic influence on rivers, the hydrological data (average, maximum and minimum values) were processed and statistically analyzed to find noticeable changes, discontinuities, and trends. The discontinuities in the data series were determined by representing and comparing the hydrographs of water stages and discharges. For consistency and comparability of data series from the four gauging stations, the stages are represented as absolute altitudes (meters above sea level).

The effects of the hydro-technical arrangements on the peak flow and the manifestation of floods are emphasized by analyzing the hydrographs of the significant floods recorded at the four gauging stations between 1980 and 2018. A flood was considered significant if the maximum discharge recorded is greater than the average of the maximum annual discharges.

The trends in the variability of the analyzed parameters were detected with Mann Kendall's test, and for each data series, the level of significance was computed (Salmi et al., 2002).

\section{Study area}

The hydrographic basin of Crişul Negru River is located in the north-western part of Romania, and it is bordered by the Crişul Repede River Basin in its northern part, the Crişul Alb River Basin in the southern part, the Someș River Basin in the eastern part; to the west, Crișul Negru crosses the border with Hungary (Fig. 1). On the Hungarian territory, Crișul Negru, Crișul Alb, and Crișul Repede join together and flow in the Tisa River.

The Crişul Negru River Basin has a total area of $4645 \mathrm{~km}^{2}$, of which $4237 \mathrm{~km}^{2}$ in Romania, and a total length of 167.7 km (164 km in Romania) (Romanian Water Cadastre Atlas, 1992; Flood Risk Management Plan, 2015).

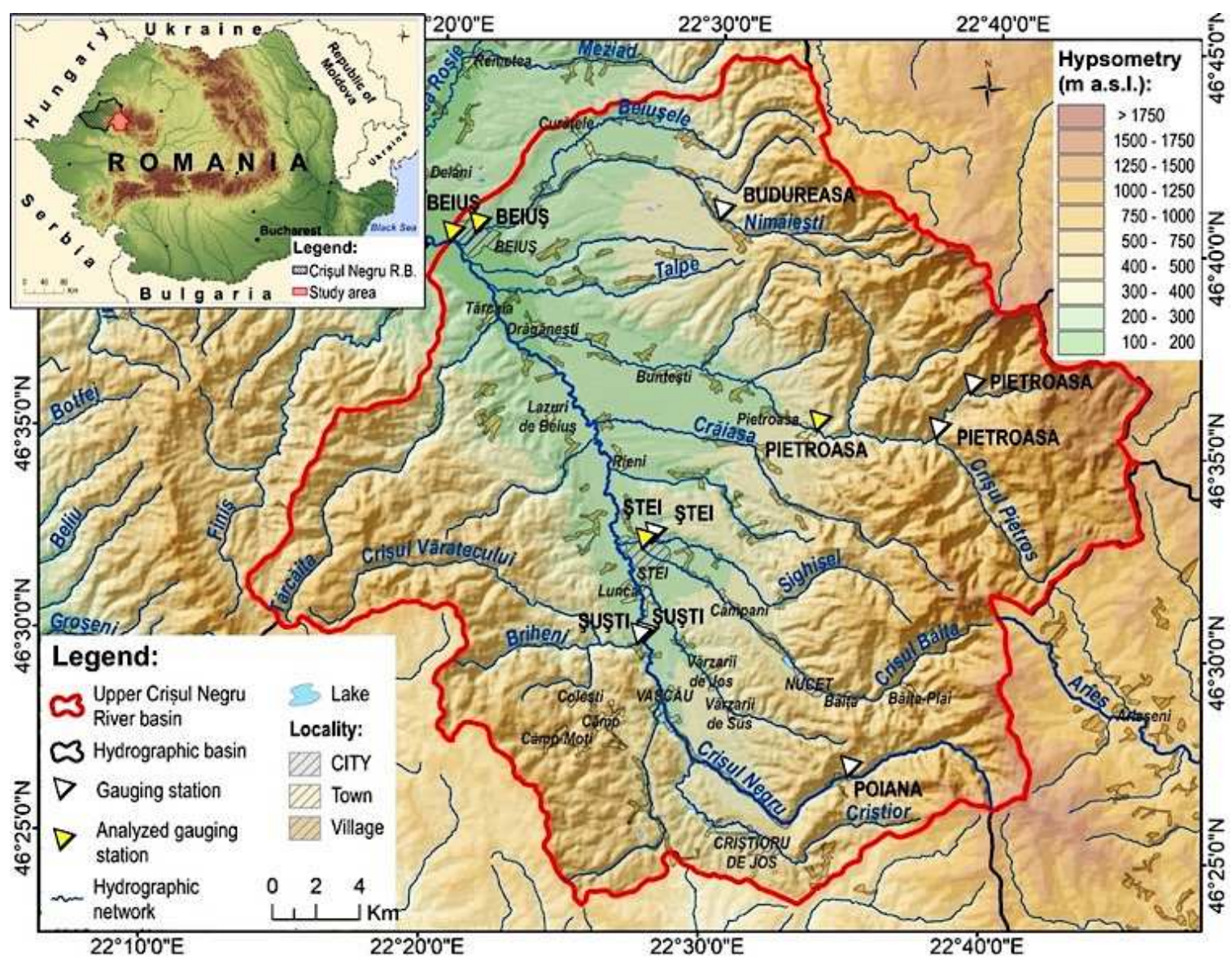

Fig. 1. The Upper Basin of Crișul Negru River: location, limits, hypsometry, hydrographic and hydrometric networks

Morphologically, the Upper Basin of Crişul Negru River extends from the collector springs in the Bihor Mountains (maximum altitude: 1849 m a.s.l., Cucurbăta Mare Peak), to the Beiuș Depression (minimum altitude: 180 m a.s.l., Beiuş City), draining the slopes of Bihor, Codru-Moma and Pădurea Craiului Mountains, the hilly region inside the mountain arc and the lower, depressionary region, where the main tributaries of Crișul Negru converge (Fig. 1).

The Upper Basin of Crișul Negru has a surface of approximately $950 \mathrm{~km}^{2}$ and a mean altitude of $580 \mathrm{~m}$, with a high river network density and relief fragmentation, especially in the north-eastern and south-western karstic areas, 
where the flow has, in general, a torrential character. In the hilly region, the slope of the riverbeds diminishes considerably, from $10 \mathrm{~m} / \mathrm{km}$ to $5-6 \mathrm{~m} / \mathrm{km}$. Consequently, the degree of torrentiality decreases, and, in the low depression area, with riverbed slopes of $2.45 \mathrm{~m} / \mathrm{km}$, the degree of sinuosity and meandering increases (Ujvári, 1972).

\section{Hydrotechnical arrangements in the Upper Basin of Crişul Negru River}

In the study area, since the $18^{\text {th }}$ century, hydro-technical works for flood effect mitigation and swampy areas improvement were done (Diaconu, 1971). In the $19^{\text {th }}$ century, after the catastrophic floods that occurred in 1830, preventive measures were taken, and the works consisted mainly of embankments and river regularization by meander cut-off (ISCH, 1968). At the beginning of the $20^{\text {th }}$ century, the works extended to irrigation and water supply systems (Diaconu, 1971).

The most important works, however, were designed and executed following the extraordinary floods of 1980 and 1981, the largest floods recorded at the gauging stations existent in the study area. The extensive works, designed for protection against floods, refer to embankments - to avoid overflowing during floods (Jora and Romanescu, 2010), bank consolidation, and protection to avoid erosion, unclogging riverbeds where appropriate, construction of bottom sills to decrease bed slopes, but also to the development of drinking and industrial water supply systems.

At present, almost all watercourses in the study area have undergone modifications from their natural state: from the river network's total length of $342 \mathrm{~km}$, on $96 \mathrm{~km}$ ( $28 \%$ of the total rivers' length), hydro-technical works were undergone over time, most of them being constructed between 1980 and 1990, but also after 1998-2000. The most frequent solutions for defence against floods are the bank protection and consolidation works and the bottom sills.

The most affected rivers in the study area are the main collector, Crișul Negru River, and its right-side tributaries Crișul Băița, Crișul Pietros, and Nimăiești (Fig. 2). These watercourses are also monitored through gauging stations, which allows the evaluation of anthropic influences by analyzing the hydrological data.

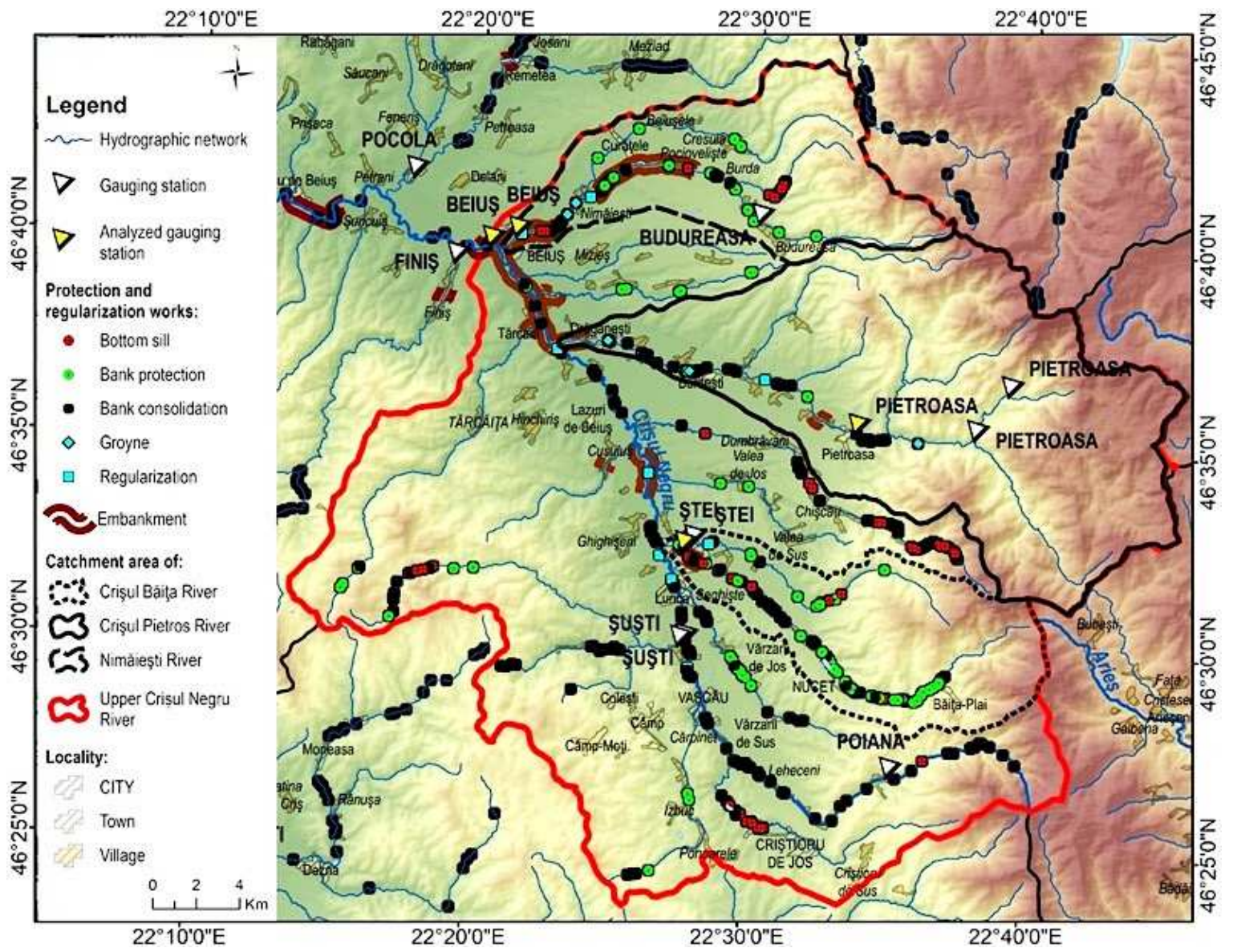

Fig. 2. Hydrotechnical works in the Upper Basin of Crişul Negru River

On the four mentioned watercourses, the arrangements have approximately $82 \mathrm{~km}$ in length, which represents approximately $60 \%$ of the rivers' total length. The length of the bank protection and consolidation works is approximately $36 \mathrm{~km}$ (26\% of the total river length), the embankments and regularization works are made on 46 $\mathrm{km}$ (34\% of the total river length), and there are 17 bottom sills and 9 groins on record.

In some cases, the interventions (consolidation, bank protection, etc.) are made on both banks, but the length of the construction is quantified by the length of the river stretch. At the same time, if on the same river stretch 
there are more than one type of hydro-technical works (for example, embankment and bank protection), only the embankment length was added to avoid exceeding the actual affected length of the rivers.

\section{Results and discussion}

The impact of the anthropic interventions on liquid runoff is quantified through comparative and statistical analysis of the main characteristics of rivers and their hydrological behaviour before and after the occurrence of the main hydro-technical works. These interventions may impact the morphology, and consequently the hydraulics of rivers, on the hydrology - mainly on the extreme discharge values - or, in some cases, on both aspects.

\section{The influence of hydro-technical arrangements on the morphological characteristics of rivers}

To capture/highlight the changes in river morphology, elevation profiles of the cross-sections at the four gauging stations were overlayed (Fig. 3 left panels). The years were chosen in accordance with the main works conducted on the river stretch of the gauging stations and upstream of their locations.
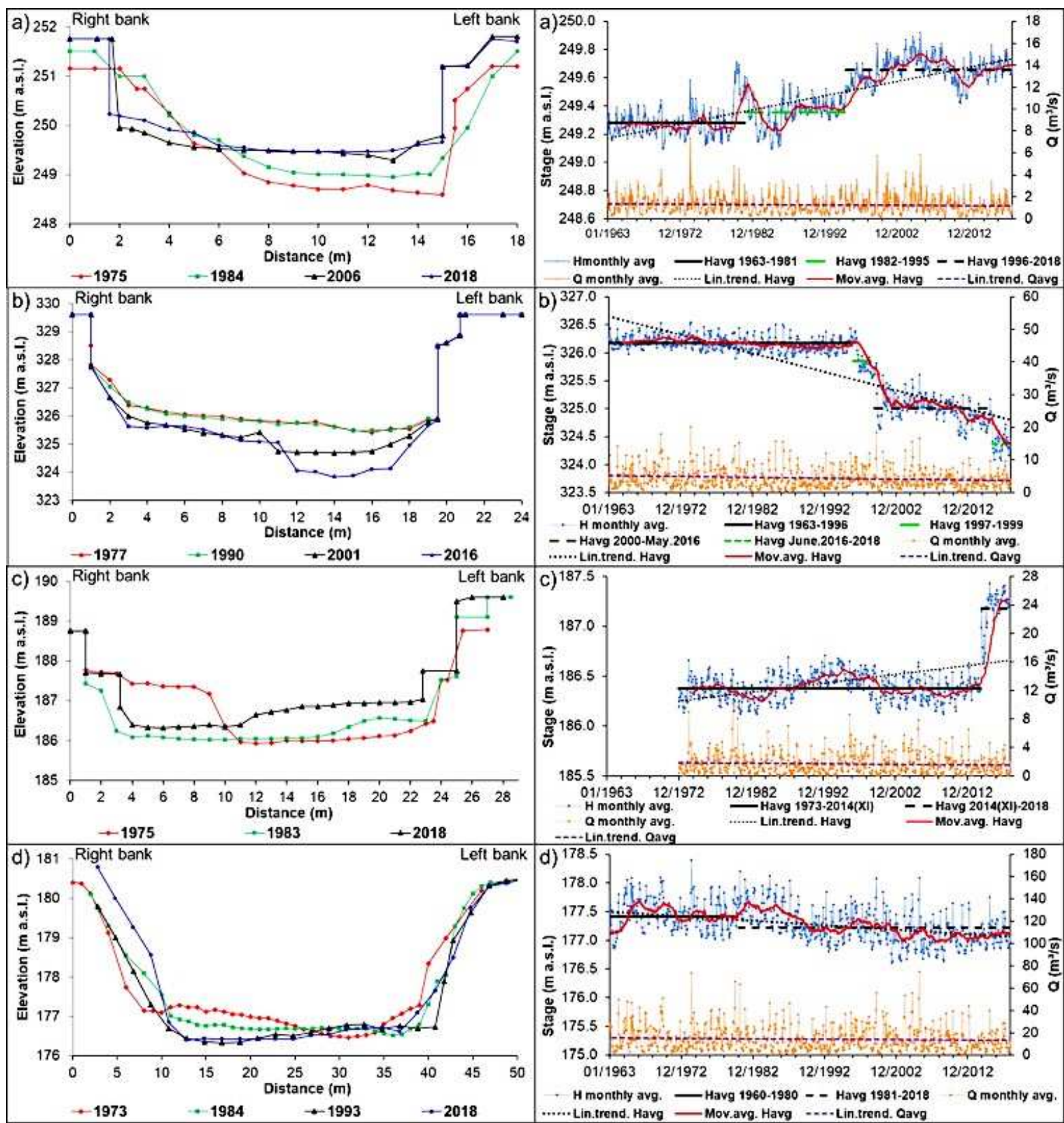

Fig. 3. Morphological changes of the cross-sections (left panels) and the variation of the average monthly stages (expressed as elevation above mean sea level), the average monthly discharges, and their linear and moving averages (on 24 months) trends (right panels) at the four analyzed gauging stations: Ștei g.st. on Crișul Băița River (a), Pietroasa g.st. on Crișul Pietros River (b), Beiuş g.st. on Nimăiești River (c), and Beiuș g.st. on Crișul Negru River (d) 
All the interventions on the morphology and the natural evolution of the riverbeds are reflected by and, at the same time, generate a direct response of the water stage variations (Fig 3 right panels).

On Crișul Băița River, the first hydro-technical works were conducted in the period 19701975 , mostly bank consolidations and a bottom sill in Ștei City. Following the extraordinary floods recorded in 1980 and 1981 in the entire basin of the Crișul Negru River, during the years 1982-1983, the regularization and embankment of the river stretch were carried out on the lower course of Crișul Băița River, within Ștei City. In the next two decades, the riverbed suffers successive degradations and aggradations caused by the periodic unclogging works that included the river stretch of the Ștei g.st. The newest works were made after 2004, mainly bank protection and consolidation, as well as bottom sills on its medium and upper course. At present, approximately $80 \%$ of the river length is affected by hydro-technical works. At the Ștei g.st., the cross-section shows radical changes in channel depth due to the clogging of the bottom sills made to reduce the energy slope, consequently the water velocity, but also in banks' shape (Fig. 3a).

Due to the geological and morphological characteristics of the basin (limestones and steep slopes in the upper and medium part), the natural hydrological regime of Crișul Pietros River is very dynamic, and the floods were often causing economic damages.

Thus, the first on-record interventions date to 1958 1960, namely bank consolidation and groins. But the largescale works were conducted in the period 1970-1975, including the embankments downstream the Pietroasa g.st. (in Cociuba Mică locality) and near the confluence with the main collector, Crișul Negru River, and continued in the late '80s, with extensive bank consolidation with gabions and groins, especially upstream the localities situated along the river. In the late '90s and the last few years, the interventions took place mainly for riverbed maintenance: regularization and unclogging of the channel on different river stretches. The river is affected by the interventions on $18 \%$ of its length. At Pietroasa g.st., the changes of the cross-section are visible especially at the beginning of the $21^{\text {st }}$ century, when the channel depth and cross-section area is gradually increased artificially to avoid the overflow of the water during floods. As a direct effect, the stages drop dramatically in 2000 and again in 2016 (Fig. 3b).

The historical floods recorded in 1980-1981 also affected the Nimăiești River Basin, which determined the need to conduct regularization and embankment works, as well as groins, bottom sills, and bank consolidation on its lower course. The torrential character of the flow and the large floods recorded at the end of the $20^{\text {th }}$ century (Mustățea, 2005) made necessary other extensive works: bank consolidation on the lower and medium course (1986, 1989, 1998), embankments on the medium course to protect the localities Nimăiești, Curățele and Pocioveliște (2000), bank protection and channel regularization (2001-2004), and some more recent works (after 2014), including bottom sills and recreation works (walkways along the river bank) in Nimăiești and Beiuș Cities. The average monthly stages show a slightly cyclic variation as a result of the natural effort of the watercourse to reach its equilibrium profile in the new, anthropologically modified conditions. With interventions on $73 \%$ of the river length, the cross-section at Beiuș g.st. shows major changes over time: first, the widening and deepening of the channel after the regularization conducted in the early '80s; then, rather sudden aggradation of the riverbed after 2013, caused by the energy slope reduction after the commissioning of several large, dam-like bottom sills (with hights of over 1-1.5 meters) (Fig. 3c).

At Beiuș g.st. and upstream on Crișul Negru River, bank protection and consolidations on different vulnerable river stretches were conducted since 1959 1960. During the '80s, in Beiuş City and neighbouring localities, the river was dammed on both banks (embankment in the floodplain). The consolidation of the banks continued gradually; at present, almost $70 \%$ of the upper course's length is affected by different types of hydro-technical works. However, the natural shape of the cross-section at the Beiuş g.st. was not significantly modified over time, except a slight deepening of the channel. Nevertheless, the average monthly stages show a progressive decrease (Fig. 3d).

At all four gauging stations, the average annual stages show strong, statistically significant linear trends. But the annual regime of the liquid flow is not impacted in the same sense as the stages: the estimated trends show a decrease of the average annual discharges in all four cases, with a rather weak level of significance only for Crișul Pietros River, at Pietroasa g.st (Tab. 2).

Tab. 2. Trend estimation with Mann-Kendall's test and the level of significance $(\alpha)$ for average annual stages and discharges recorded at gauging stations from the Upper Basin of Crișul Negru River; the sign shows the sense of the trend: negative values - a downward trend,

\begin{tabular}{|r|l|l|c|c|c|c|}
\hline \multirow{2}{*}{ No. } & \multirow{2}{*}{ River } & \multirow{2}{*}{ Gauging station } & \multicolumn{2}{|c|}{ Average annual stages } & \multicolumn{2}{c|}{ Average annual discharges } \\
\cline { 4 - 7 } & & & Trend estimation & $\alpha$ & \multicolumn{2}{c|}{ Trend estimation } \\
\hline & & Crișul Băița & Ștei & 6.58 & 0.001 & -1.32 \\
\hline & Crișul Pietros & Pietroasa & -8.50 & 0.001 & -2.58 \\
\hline 3 & Nimăiești & Beiuș & 2.23 & 0.05 & -0.93 \\
\hline 4 & Crișul Negru & Beiuș & -5.00 & 0.001 & - \\
\hline
\end{tabular}




\section{The influence of hydro-technical arrangements on the hydrological characteristics of rivers}

The purpose of the hydro-technical arrangements conducted in the Upper Basin of Crișul Negru River is flood protection, hence the mitigation of maximum discharges by water velocity reduction and/or section area increase on river stretches prone to flooding.

Following the works made on the four analyzed rivers, the maximum annual discharges show a downward trend, statistically significant for all but Nimăiești River, at Beiuș g.st., where the effect of the bottom sills made on its lower course should be significant during high flow periods in a few years, after the stabilization of the riverbed in the new conditions of the longitudinal profile (Fig. 4, Tab. 3).

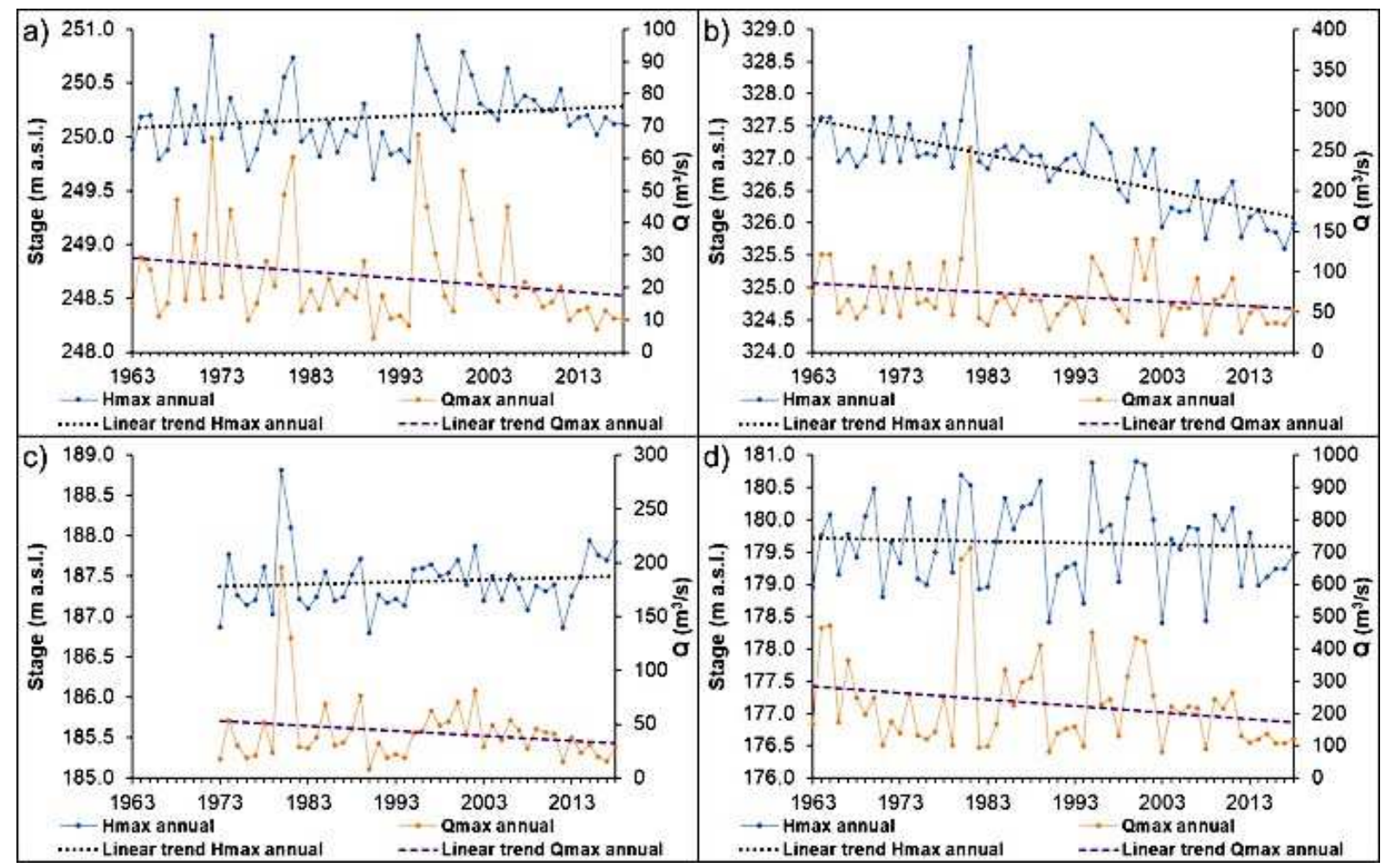

Fig. 4. The variation of the maximum annual stages (expressed as elevation above mean sea level), the maximum annual discharges, and their linear and moving average (on 24 months) trends at Ștei g.st. on Crișul Băița River (a), Pietroasa g.st. on Crişul Pietros River (b), Beiuş g.st. on Nimăiești River (c), and Beiuș g.st. on Crișul Negru River (d)

For the maximum annual stages, the trends have positive values (upward trends) for Crișul Băița and Nimăiești Rivers and negative values for the Crișul Pietros and Crișul Negru Rivers, situation imposed by the type of structural measures taken.

Tab. 3. Trend estimation with Mann-Kendall's test and the level of significance $(\alpha)$ for maximum annual stages and discharges recorded at gauging stations from the Upper Basin of Crișul Negru River; the sign shows the sense of the trend: negative values - a downward trend,

\begin{tabular}{|c|c|c|c|c|c|c|}
\hline \multirow{2}{*}{ No. } & \multirow{2}{*}{ River } & \multirow{2}{*}{ Gauging station } & \multicolumn{2}{|c|}{ Maximum annual stages } & \multicolumn{2}{|c|}{ Maximum annual discharges } \\
\hline & & & Trend estimation & $\alpha$ & Trend estimation & $\alpha$ \\
\hline 1 & Crişul Băiţa & Ştei & 1.64 & - & -2.08 & 0.05 \\
\hline 2 & Crişul Pietros & Pietroasa & -5.89 & 0.001 & -1.97 & 0.05 \\
\hline 3 & Nimăieşti & Beiuş & 1.39 & - & -0.46 & - \\
\hline$\overline{4}$ & Crișul Negru & Beius & -0.30 & - & -1.82 & 0.1 \\
\hline
\end{tabular}

On the cross-sectional profiles from the gauging stations (Fig. 3 left panels), it stands out that the evolution towards the degradation of the riverbed, hence the enlargement of the section area, coincides with the downward trend in terms of maximum annual stages and vice versa. However, a strong and statistically significant trend of the stages is met just for Crișul Pietros River, at Pietroasa g.st., where the unclogging and the removal of blocks and boulders takes place periodically on its lower course.

The anthropic impact on the natural flow regime is even better emphasized by the trends detected for the main parameters of the significant floods (with peak discharges greater than the average of the maximum annual discharges): duration, total water volume, and form coefficient. 
At Ștei g.st., for the floods analyzed, the decrease of the water volumes together with an increase of the shape coefficient values, which means that, due to the bottom sills on the medium and lower course of Crișul Băița River, the floods are "flattened" as form, and attenuated as phenomena (Fig. 5a).

For Crișul Pietros and Crișul Negru Rivers, the data recorded at the gauging stations show that, in time, the interventions have the expected result (or, at least, have a role in the changes observed): the floods' duration has an upward trend, but with a decrease of the water volumes and form coefficients (Fig. 5b and d). Hence, the floods are less destructive and reach the base flow quicker, their prolonged duration being the result of a longer decrease time.

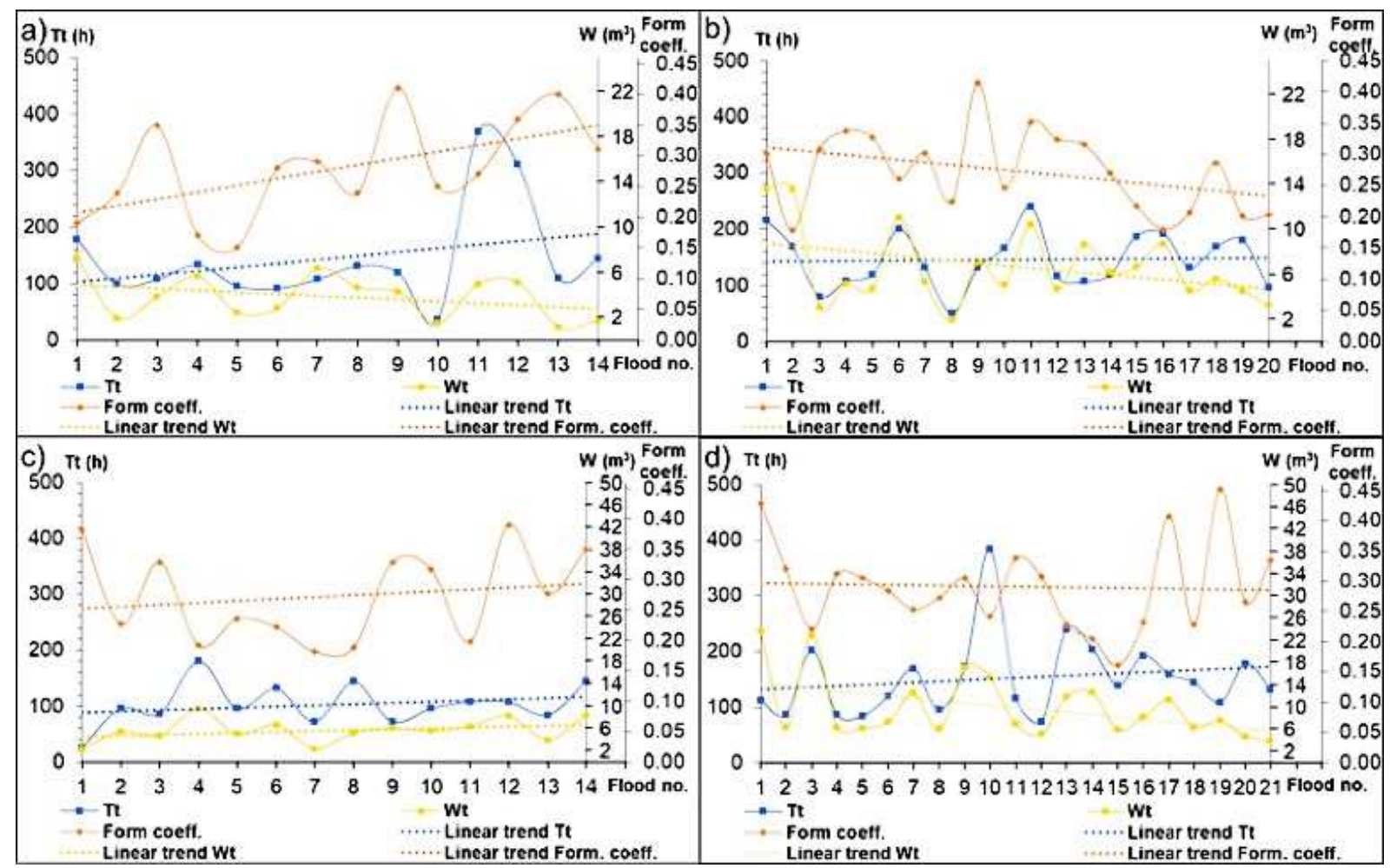

Fig. 5. Variation graphs of the water volumes (Wt), total duration (Tt), and shape coefficients of floods with the peak discharge greater than the average of the maximum annual discharges, recorded in the period 1980-2018 at Ștei g.st. on Crișul Băița River - 14 floods (a), Pietroasa g.st. on Crișul Pietros River - 20 floods (b), Beiuș g.st. on Nimăiești River - 14 floods (c), and Beiuș g.st. on Crișul Negru River - 21 floods $(d)$

On the Nimăiești River, the torrential character of the rivers' natural regime is only in part attenuated by the hydro-technical works, as the flood parameters record an upward trend for the events analyzed (Fig. 5c), despite the decreasing trend detected in the maximum annual discharges.

However, except the trends detected for the form coefficient at Ștei and Pietroasa g.st and the total water volumes at Beiuș g.st. (on Crișul Negru River), a level of statistical significance was not determined (Tab. 4). For a conclusive result, it could be necessary to analyze a larger number of significant floods corroborated with the variation of the precipitation amounts.

Tab. 4. Trend estimation with Mann-Kendall's test and the level of significance $(\alpha)$ for three parameters of floods recorded at gauging stations from the Upper Basin of Crișul Negru River between 1980 and 2018; the sign shows the sense of the trend: negative values - $a$

\begin{tabular}{|c|c|c|c|c|c|c|c|c|c|}
\hline \multirow{2}{*}{ No. } & \multirow{2}{*}{ River } & \multirow{2}{*}{ Gauging station } & \multirow{2}{*}{$\begin{array}{l}\text { No. of floods } \\
\text { analyzed }\end{array}$} & \multicolumn{2}{|c|}{ Total duration $(\mathrm{Tt})$} & \multicolumn{2}{|c|}{ Total water volume (Wt) } & \multicolumn{2}{|c|}{ Form coefficient $(\gamma)$} \\
\hline & & & & $\mathrm{Z}$ test & $\alpha$ & $\mathrm{Z}$ test & $\alpha$ & $\mathrm{Z}$ test & $\alpha$ \\
\hline & 1)Crişul Băiţa & Ştei & 14 & 0.71 & - & -0.99 & - & 2.03 & 0.05 \\
\hline & 2Crişul Pietros & Pietroasa & 20 & 0.23 & - & -1.33 & - & -1.78 & 0.1 \\
\hline & 3 Nimăieşti & Beiuş & 14 & 0.88 & - & 1.53 & - & 0.33 & - \\
\hline & 4/Crişul Negru & Beiuş & 21 & 1.03 & - & -2.02 & 0.05 & -0.75 & - \\
\hline
\end{tabular}

Even though the river interventions in the study area are made exclusively for flood effects mitigation, they also may have an impact on low flows and minimum discharges. In the case of the data recorded at the four gauging stations in the study area, the minimum annual discharges tend to decrease, with the strongest decreasing trend at Nimăiești g.st, on Crişul Negru River. The minimum annual stages show the same sense of the trends as the maximum annual values, in concordance with the type of works conducted (Fig. 6, Tab. 5). 
The fact that the bottom sills made on the lower course of the Nimăiești River are rather recent, the trend for the stages has not a level of statistical significance, but in terms of discharge, the level of significance is 0.001 .

Except for Nimăiești River, the trends in minimum annual discharges may also be the result of changes in the precipitation amounts, although, for the western part of the country and especially for the mountainous areas, the studies show stable or upward trends for the precipitation annual regime (Marin et al., 2014) and mixed, with no statistical significance for the extreme values (Dumitrescu et al., 2014).
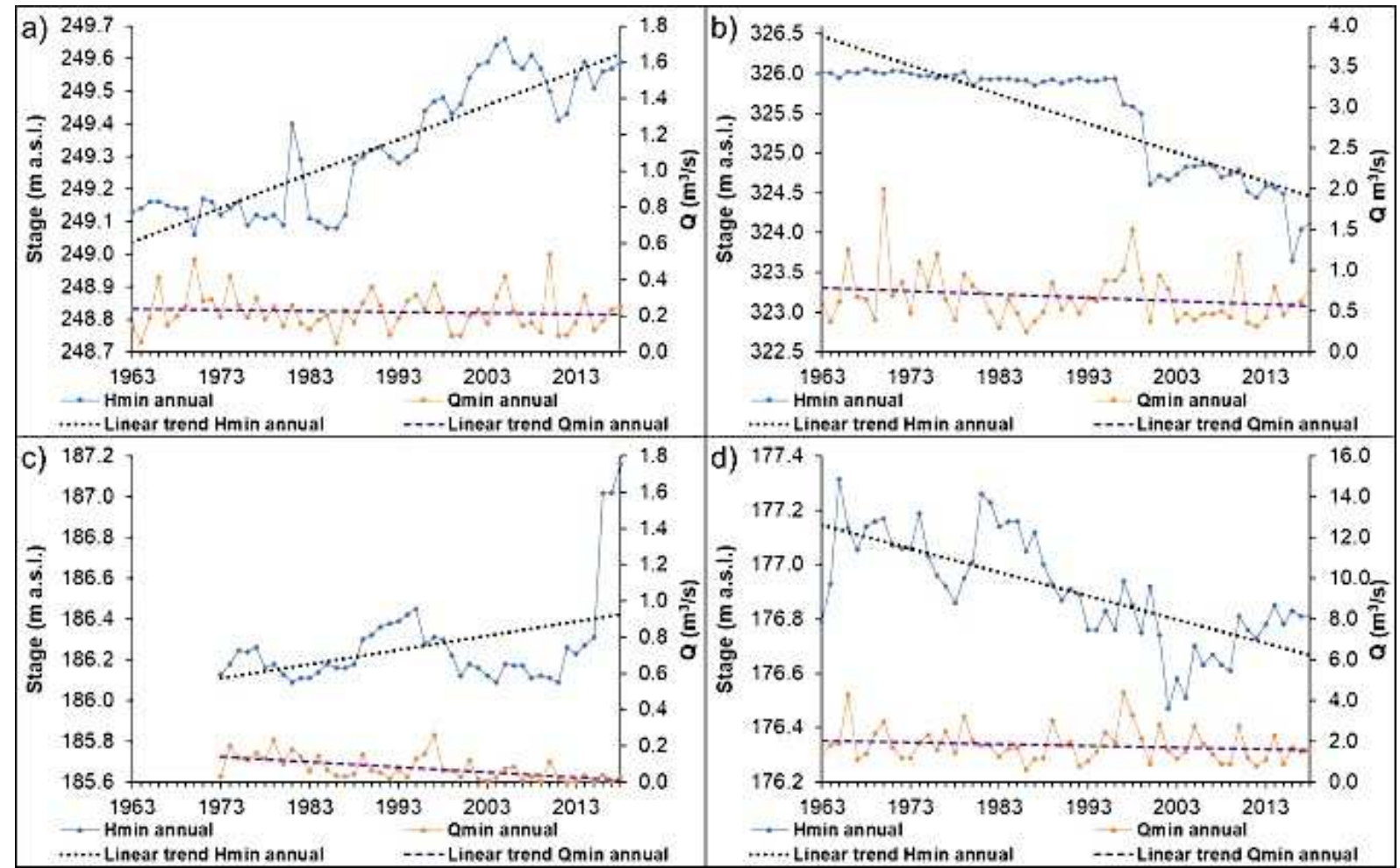

Fig. 6. The variation of the minimum annual stages (expressed as elevation above mean sea level), the minimum annual discharges, and their linear and moving average (on 24 months) trends at Ștei g.st. on Crișul Băița River (a), Pietroasa g.st. on Crișul Pietros River (b), Beiuș g.st. on Nimăiești River (c), and Beiuș g.st. on Crișul Negru River (d)

Tab. 5. Trend estimation with Mann-Kendall's test and the level of significance $(\alpha)$ for minimum annual stages and discharges recorded at gauging stations from the Upper Basin of Crișul Negru River; the sign shows the sense of the trend: negative values - a downward trend,

\begin{tabular}{|c|c|c|c|c|c|c|}
\hline \multirow{2}{*}{ No. } & \multirow{2}{*}{ River } & \multirow{2}{*}{ Gauging station } & \multicolumn{2}{|c|}{ Minimum annual stages } & \multicolumn{2}{|c|}{ Minimum annual discharges } \\
\hline & & & $Z$ test & $\alpha$ & $Z$ test & $\alpha$ \\
\hline 1 & Crişul Băiţa & Ştei & 6.37 & 0.001 & -0.76 & - \\
\hline 2 & Crişul Pietros & Pietroasa & -8.49 & 0.001 & -1.29 & - \\
\hline 3 & Nimăieşti & Beiuş & 1.34 & - & -4.44 & 0.001 \\
\hline 4 & Crișul Negru & Beiuş & -5.69 & 0.001 & -1.36 & - \\
\hline
\end{tabular}

\section{Conclusions}

The interventions in the Upper Basin of Crișul Negru River are extensive and have as main purpose the mitigation of flood effects. Most of them were conducted in the second part of the XXth century, before the new perspective and concern of the European states for the hydromorphological status of rivers and sustainable management. Therefore, the present paper presents the effects of such works on a mountainous basin in which, due to its natural characteristics, floods are extremely frequent and often caused damages due to water overflow (Mihalea et al., 2020)

The main works conducted on Crișul negru River and its tributaries are embankments on their lower courses and bank consolidations, which determined riverbed degradation, and a large number of bottom sills for energy slope reduction; hence they determined the aggradation of the riverbeds.

The statistical analysis showed that in all the four study cases, the maximum annual discharges tend to decrease, with stronger trends on Crișul Băița and Crișul Pietros rivers (at Pietroasa and Ștei g.st.). Regarding the flood parameters, their trends show that the interventions determined the expected results, except for the Nimăiești River, 
where, even though the trend of maximum annual discharges shows a slight decrease, statistically not significant, the duration of the significant floods and the water volumes tend to increase. In conclusion, the structural measures taken on the Nimăiești River could be ineffective or inappropriate for the river's natural characteristics.

At the same time, the intrusive and extended interventions have undeniable negative effects on low flows, whose decrease is dramatic (in the last decade, on its lower course, the Nimăieşti River tends to dry out, the average of minimum annual discharges decreasing from $0.101 \mathrm{~m} 3 / \mathrm{s}$ for the period 1973-1995, to $0.052 \mathrm{~m} 3 / \mathrm{s}$ for the period $1994-2018$, and absolute minimum values from $0.018 \mathrm{~m} 3 / \mathrm{s}$ to $0.001 \mathrm{~m} 3 / \mathrm{s}$ ).

To protect both, the surface water resources and the ecological status of the Nimăieşti River, a more appropriate constructive measure should be undergone, for example, the commissioning of a lateral or transversal nonpermanent reservoir to retain and redistribute water volumes during floods but to ensure a proper hydrological regime in low flow periods.

\section{References}

Adamec, M., Trizna, M., Ř́íhová, V., Unucka, J., Gergel’ová, M. (2012), On 2D and 3D parameter derivation for rainfall-runoff models. Acta Montanistica Slovaca, Volume 17, number 3, 204-208.

Blistanova, M., Zeleňáková, M., Blistan, P., Ferencz, V. (2016), Assessment of flood vulnerability in Bodva river basin, Slovakia. Acta Montanistica Slovaca Volume 21, number 1, 19-28.

Bosa, S., Petti, M., Pascolo, S. (2020), A Complete Morphodynamic Study to Face a River Engineering Issue. IOP Conf. Series: Materials Science and Engineering 960 (2020) 032034, p. 1-10, doi:10.1088/1757899X/960/3/032034.

Cârstinoiu, C., Deak, G., Urițescu, B., Tudor, G., Nicolae, A.F., Zamfir, A.Ș., Dănălache, T., Olteanu, M., Raischi, M. (2017), Assessment of Hydromorphological and Hydrodynamic Alterations Caused by Anthropogenic Interventions on the Riverbed. Case Study Danube Bala Branch New Bottom Sill. RevCAD 23/2017, „1 Decembrie 1918" University of Alba Iulia, p. 49-58.

Corrado Cencetti, C., Paolo Tacconi, P. (2005), The Fluvial Dynamics of the Arno River. Giornale di Geologia Applicata 1 (2005) 193 -202, doi: 10.1474/GGA.2005-01.0-19.0019

Costea, M. (2013), Some Geomorphologic Aspects Along the Timiş River in the Romanian Sector. Transylv. Rev. Syst. Ecol. Res. 15 - special issue, (2013), "The Timiş River Basin", p. 23-32, DOI: 10.2478/trser-20130030.

Cîrţînă, D., Pecingină, R.I. (2013), Considerations Regarding the Impact Produced on the Environment by the Arrangement of the Water Resources. Annals of the "Constantin Brancusi" University of Targu Jiu, Engineering Series, No. 3, p. 72-77.

Chow, V.T. (1981), Open-channel hydraulics", MacGraw- Hill, London.

Danalache, T.M., Deák, G., Holban, E., Raischi, M.C., Fronescu, D.S., Nicolae, C.G., Cristea, M.-A. (2020), Evaluating the Effect of the Hydrotechnical Works from the Danube's Caleia Branch on the Spawning Migration of Sturgeons. 2nd International Conference on Green Environmental Engineering and Technology, IOP Conf. Series: Earth and Environmental Science 616 (2020) 012025 doi:10.1088/1755$1315 / 616 / 1 / 012025$

Diaconu, C. (1971), Romanian Rivers - Hydrological Monograph (in Romanian), Edit. Institutului Național de Meteorologie şi Hidrologie, Bucureşti.

Diaconu, S. (1999), Water courses. Arrangement, impact, rehabilitation (in Romanian). Edit. HGA, Bucureşti

Dumitrescu, A., Bojariu, R., Bîrsan, M.V., Marin, L., Manea, A. (2014), Recent climatic changes in Romania from observational data (1961-2013). Theoretical and Applied Climatology, 122(1-2), pp. 111-119.

Ichim, I., Rădoane, M. (1986), Dams efects in relief dynamics. Geomorphological approach (in Romanian). Edit. Academiei Republicii Socialiste România, Bucureşti, 157 p.

Ichim, I., Bătuca, D., Rădoane, Maria, Duma, D. (1989), - Morfologia şi dinamica albiilor de râu, Editura Tehnica, Bucuresti, $408 \mathrm{p}$.

Jora, I., Romanescu, G. (2010), Influence of anthropogenic activities on Vaslui River hydrological regime (in Romanian). Proceedings of the First National Symposium "Resursele de Apă din România - Vulnerabilitate la presiunile antropice", Târgoviște, România, pp. 201-208.

Leopold, L.B., Wolman, M.G. (1957), River channel pattern-braided, meandering, and straight, U.S. Geol. Survey Prof., paper 282B, pp. 39-85.

Leopold, L.B., Wolman, M.G. (1960), River meanders, Bulletin of the geological society of America, vol. 71, pp. 769-794.

Loghin, V., Murătoreanu, G., Rogojină, A. (2011), Anthropic Modifications of the Riverbeds of Ialomiţa and Ialomicioara Upstream from their Confluence in Fieni. The Annals of Valahia University of Târgovişte, Geographical Series, Tome 11, p. 19-24. 
Mandarino, A., Pepe, G., Maerker, M., Cevasco, A., Brandolini, P. (2020), Short-Term GIS Analysis for the Assessment of the Recent Active-Channel Planform Adjustments in a Widening, Highly Altered River: The Scrivia River, Italy. Water 2020, 12, 514; p. 1-22, doi:10.3390/w12020514

Marin, L., Bîrsan, M.V., Bojariu, R., Dumitrescu, A., Micu, D.M., Manea, A. (2014), An overview of annual climatic changes in Romania: trends in air temperature, precipitation, sunshine hours, cloud cover, relative humidity and wind speed during the 1961-2013 period. Carpathian Journal of Earth and Environmental Science 9(4), pp. 253-258.

Mihalea, D.-M., Perju, R., Lupu, I., Ungureanu, M., Lăzuran (Axinte), A.L. (2020), The Characteristics of the Maximum Flow in the Upper Basin of Crişul Negru River. 2020" Air and Water - Components of the Environment" Conference Proceedings, Cluj-Napoca, Romania, p. 157-168, DOI: 10.24193/AWC2020_15

Mititelu, L.A. (2010), Vidraru Reservoir, Romania. Environmental Impact of the Hydrotehnical Constructions on the Upper Course of Arges River. Lakes, reservoirs and ponds, vol. 4(2): 152-166.

Mustățea, A. (2005), Exceptional flash-floods on Romanian teritorry. Genesis and effects (in Romanian). S.C. "ONESTA.COM PROD 94" S.R.L., București.

Neuhold, C., Stanzel, Ph., Nachtnebel, H.P. (2011), Integrating River Bed Dynamics to Flood Risk Assessment. In" Sediment Transport in Aquatic Environments". Manning, A.J. edit., IntechOpen, 317-332, DOI: $10.5772 / 827$

Obodovsky, A. (2004), The assessment of Ukrainian riverbed deformation. Sediment Transfer through the Fluvial System (Proceedings of a symposium held in Moscow, August 2004). IAHS Publ. 288, p. 253-260.

Pandi, G., Horvath, Cs. (2013), Mureş River Middle Course Riverbed Dynamics Between the Arieş and Strei Confluences. 2013" Air and Water -Components of the Environment" Conference Proceedings, ClujNapoca, Romania, p. 49-56.

Romanescu G., Stoleriu C., Romanescu A.M. (2011), Water reservoirs and the risk of accidental flood occurrence. Case study: Stanca-Costesti reservoir and the historical floods of the Prut River in the period July-August 2008, Romania, Hydrological Processes, 25:2056-2070. Doi: 10.1002/hyp.7957.

Roşian, Gh., Muntean, L., Măcicăşan, V., Rusu, R., Arghiuş, V. (2012), Dynamics of Brâglez Riverbed (Someşan Plateau). 2012"Air and Water-Components of the Environment" Conference Proceedings, ClujNapoca, Romania, p. 259-264.

Sabău, D.A., Haidu, I., Şerban, Gh. (2020) Key Types of Anthropic Influence on Surface Waters, Components of Spatial Decision Support System for Prevention and Management of Floods (Firiza Basin). 2020" Air and Water -Components of the Environment" Conference Proceedings, Cluj-Napoca, Romania, p. 177-190, DOI: 10.24193/AWC2020_17

Salmi, T., Määttä, A., Anttila, P., Ruoho-Airola, T., Amnell, T. (2002), Detecting trends of annual values of atmospheric pollutants by the Mann-Kendall test and Sen's slope estimates - the Excel template application MAKESENS, Air Quality, No. 31, Report code FMI-AQ, Helsinki.

Sekulic, G., Cipranic, I. (2015), Benefits of Multi-Purpose Hydrotechnical Systems in Urban Areas of Developing Countries, Example od Montenegro. Procedia Engineering 117, 646 - 654.

Sergaliev, N.Kh., Akhmedenov, K.M. (2014), Dynamics of river bed processes of the Ural River in Western Kazakhstan. Water Practice \& Technology, Vol 9, No 4, IWA Publishing, 457-463, doi: 10.2166/wpt.2014.050

Simon, A. (1995), Adjustment and recovery of unstable alluvial channels: identification and approaches for engineering management, Earth Surface Processes and Landforms, 20, pp. 611-628.

Şelărescu, M., Podani, M. (1993), Defense against the floods (in Romanian). Edit. Ştiinţifică, Bucureşti.

Şerban, Gh. (2007), The reservoirs from the upper basin of Someşul Mic river. Hydrogeographic study (in Romanian). Edit. Presa Universitară Clujeană, Cluj-Napoca, 236 p.

Şerban, Gh., Sorocovschi, V., Fodorean, I. (2004), Risks induced by the hydrotechnical arrangement of the ponds on the Şesului Valley (Transylvanian Plain) (in Romanian). In journal „Riscuri şi catastrofe”, Editor Sorocovschi, V., Vol. III, Edit. Casa Cărţii de Ştiinţă, Cluj-Napoca, pp. 159-170.

Sofronie, C. (2000), Hydrotechnical arrangements in the Someş-Tisa river basin (in Romanian). Casa de editură Gloria, Cluj-Napoca.

Teodorescu, I. Filotti, A., Chiriac, V. Ceaușescu, V., Florescu, A. (1982), Water Management (in Romanian). Edit. Ceres, București.

Ujvari, L. (1972), Geography of Romanian Waters (in Romanian). Edit. Stiinţifică, Bucureşti.

Vesipa, R., Camporeale, C., Ridolfi, L. (2018), Hydraulics of braided river dynamics. Insights from flume experiments. E3S Web of Conferences 40, 02020, River Flow 2018, p. 1-8, https://doi.org/10.1051/e3sconf/20184002020

Wolman, M.G. (1954) A Method of Sampling Coarse River-Bed Material. Transactions-American Geophysical Union, 35, 951-956. http://dx.doi.org/10.1029/TR035i006p00951 
Zaharia, L., Grecu, F., Toroimac, G.I., Neculau, G. (2011), Sediment Transport and River Channel Dynamics in Romania - Variability and Control Factors. In" Sediment Transport in Aquatic Environments". Manning, A.J. edit., IntechOpen, 317-332, DOI: 10.5772/827

Zeleňáková, M., Dobos, E., Kováčová, L., Vágo, J., Abu-Hashim, M., Fijko, R., Purcz, P. (2018), Flood vulnerability assessment of Bodva cross-border river basin. Acta Montanistica Slovaca Volume 23, number 1, 53-61.

Zeleňáková, M., Repel, A., Vranayová, Z., Kaposztasová, D., Abd-Elhamid, H.F. (2019), Impact of land use changes on surface runoff in urban areas - Case study of Myslavsky Creek Basin in Slovakia. Acta Montanistica Slovaca Volume 24 (2019), number 2, 129-139.

Zhou, T., Bao, J., Huang, M., Hou, Z., Arntzen, E., Song, X., Harding, S.F., Titzler, P.S., Ren, H., Murray, Ch.J., Perkins, W.A., Chen, X., Stegen, J.C., Hammond, G.E., Thorne, P.D., Zachara, J.M. (2018), Riverbed hydrologic exchange dynamics in a large regulated river reach. Water Resources Research, 54, 2715-2730. https://doi.org/10.1002/2017WR020508

*** (1968), Hydrological Monograph of Crișuri Watershed (in Romanian), Studii de hidrologie, XXIV, ISCH, Bucureşti.

*** (1992), Romanian Water Cadastre Atlas. Part I, Morpho-hydrographic data on surface hydrographic network (in Romanian), Ministerul Mediului.

*** (2011), Sediment Transport in Aquatic Environments. Manning, A.J. edit., IntechOpen, DOI: 10.5772/827

*** (2015), Flood Risk Management Plan -" Crișuri" Regional Water Bazin Administration (in Romanian). Viewed 28 december 2020. https://rowater.ro/despre-noi/descrierea-activitatii/managementul-situatiilor-deurgenta/directiva-inundatii-2007-60-ce/planul-de-management-al-riscului-la-inundatii/planul-demanagement-al-riscului-la-inundatii/ 